\title{
Successful surgical repair of a chronic left ventricular pseudoaneurysm
}

\author{
Katarzyna Wdowiak-Okrojek ${ }^{1}$, Piotr Lipiec ${ }^{1}$, Monika Szewczyk ${ }^{2}$, Andrzej Lubiński ${ }^{2}$, Jarosław D. Kasprzak ${ }^{1}$ \\ ${ }^{1}$ Chair and Department of Cardiology, Medical University of Lodz, Poland \\ ${ }^{2}$ Department of Interventional Cardiology, Cardiodiabetology, and Cardiac Rehabilitation, $1^{\text {st }}$ Chair of Cardiology \\ and Cardiac Surgery, Medical University of Lodz, Poland
}

Kardiochirurgia i Torakochirurgia Polska 2013; 10 (3): 279-282

\begin{abstract}
A 53-year-old patient, previously in good health condition, was admitted to the Cardiology Department with a history of chest pain and ECG abnormalities suggesting a recent myocardial infarction. Troponin level was not elevated, but the echocardiogram revealed a huge aneurysm with possible wall rupture and thrombus adjacent to the apex. The ejection fraction was very low, estimated for $23 \%$. The magnetic resonance imaging confirmed the primary diagnosis of pseudoaneurysm. Treatment with ACE-i and diuretics was initiated, and the patient was discharged in stable condition. Subsequently, the case was discussed with cardiac surgeons: despite high risk, the patient was qualified for operation. The left ventricle was reconstructed with a bovine pericardial patch using the Menicanti method, and the patient recovered well. The control echocardiogram showed significant improvement of left ventricular contractility with ejection fraction of $35 \%$.

Key words: pseudoaneurysm, reconstruction of the left ventricle.
\end{abstract}

\section{Introduction}

At present, the incidence of mechanical complications of myocardial infarction occur less frequently due to the wide availability of interventional treatment for coronary artery disease. However, each complication constitutes significant risk for the patient and requires rapid diagnosis and urgent therapeutic decision due to unfavorable prognosis. The quantitative assessment of the incidence of these complications is difficult, as a significant percentage is only recognized through autopsy; it is likely that many cases are never revealed. Diagnosing these complications in their chronic phase, may be especially challenging in terms of further treatment, as illustrated by the following case study.

\section{Streszczenie}

Pacjent, 53 lata, dotychczas przewlekle nieleczony, zostat przyjęty do Kliniki Kardiologii z powodu epizodu bólu w klatce piersiowej z elektrokardiograficznymi cechami przebytego zawału serca. Markery martwicy nie były podwyższone, ale badanie echokardiograficzne ujawniło duży tętniak z podejrzeniem przerwania ściany mięśnia lewej komory, wytapetowany skrzepliną, oraz istotnie obniżoną funkcję skurczową lewej komory oszacowaną na $23 \%$. W badaniu metodą rezonansu magnetycznego potwierdzono obraz tętniaka rzekomego. Włączono leczenie niewydolności serca i pacjent w stanie stabilnym zostat wypisany. Po konsultacji kardiochirurgicznej, pomimo znacznego ryzyka związanego z wykonaniem zabiegu, pacjent został zakwalifikowany do rekonstrukcji lewej komory. Operację wykonano metodą Menicantiego z wszyciem łaty z osierdzia wołowego, uzyskując optymalny efekt zabiegu. Po kilkunastotygodniowym okresie rekonwalescencji pacjent stawił się na kontrolne badanie echokardiograficzne, podczas którego frakcję wyrzutową lewej komory oceniono na 35\%. Słowa kluczowe: tętniak rzekomy, rekonstrukcja lewej komory.

\section{Case study}

The 53-year-old man, previously in good condition, was admitted to the Cardiology Department due to chest pain and electrocardiographic abnormalities suggesting recent anterior wall infarction. The patient's history revealed strong chest pain approximately two weeks before admission and dyspnea while little exertion during the following days. The initial and control levels of myocardial necrosis markers were negative. The echocardiogram showed an extensive akinetic aneurysm of the left ventricle (with the suspicion of pseudoaneurysm) with a large immobile thrombus adhering to $2 / 3$ of the apical part of the lateral wall and $1 / 3$ of the left ventricular apex. The ejection fraction was estimated

Address for correspondence: lek. Katarzyna Wdowiak-Okrojek, Chair and Department of Cardiology, Medical University of Lodz, Kniaziewicza 1/5, 91-347 Łódź, Poland, tel./fax +48 4225160 15, e-mail: catarinaw@wp.pl 
at $23 \%$. There were no pericardial fluid or signs of pericardial tamponade present. The typical medications for congestive heart failure were implemented; the patient was not qualified for invasive diagnostics at this stage. After a clinical stabilization, the 6-min walk test was done; patient achieved the distance of $350 \mathrm{~m}$ and was discharged.

Magnetic resonance imaging confirmed the rupture of the myocardial wall with the presence of a massive thrombus filling the pericardial sac. After approximately 3 weeks, the patient was readmitted due to hematuria and concomitant anginal pain. Based on abdominal ultrasonography, focal urinary bladder lesion was suspected. At this point, coronary angiogram was performed and revealed the $80 \%$ left anterior descending and marginal artery stenosis and 50\% of right coronary artery stenosis. Subsequently, the patient underwent successful transvesical urinary bladder tumor removal (histopathological result: Ca urotheliale papillare G-1 non invasivum). Concurrently, he underwent cardiac evaluation and was qualified for left ventricular aneurysm repair at the Silesian Center of Heart Diseases in Zabrze. Due to the high risk associated with the reconstruction procedure, the prevalence of insufficiency symptoms, and the lack of

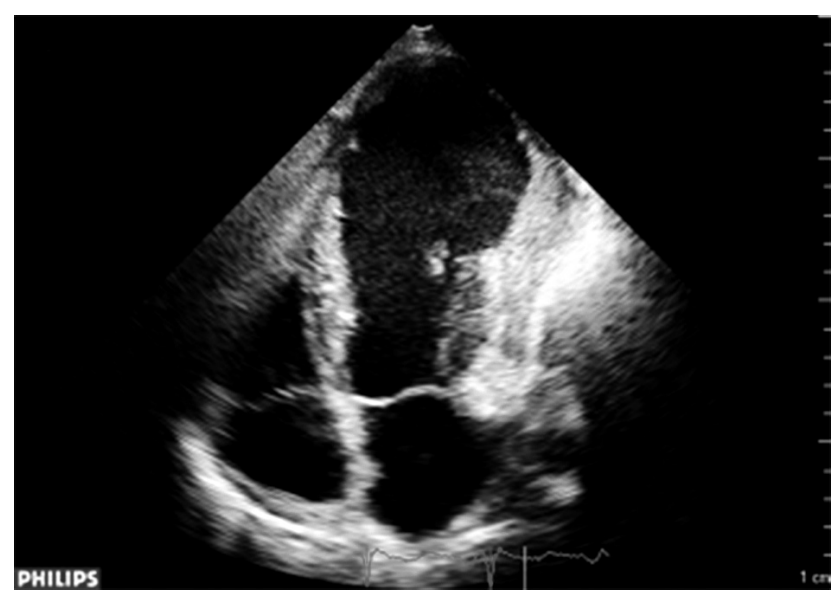

Fig. 1. Echocardiographic examination. Apical four-chamber view. The extensive aneurysm spread over the apex and a significant portion of the lateral wall

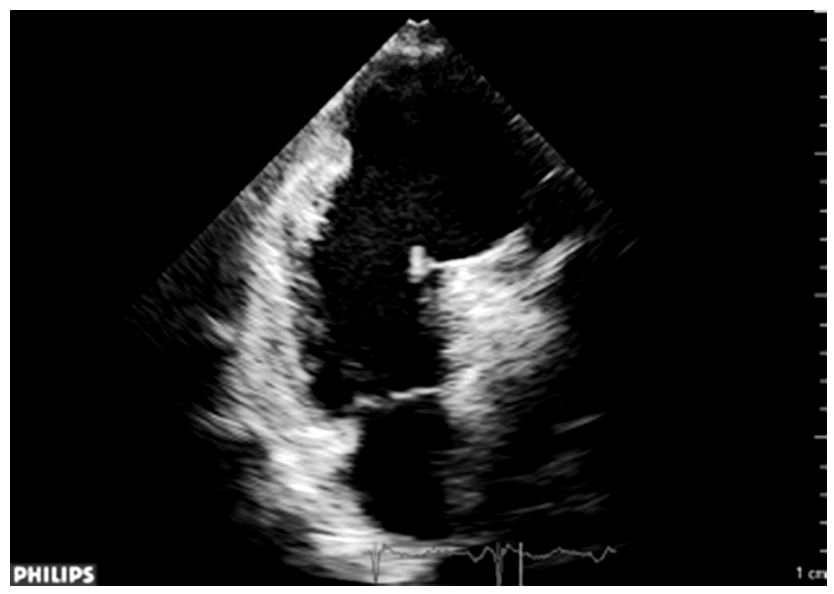

Fig. 2. Apical two-chamber view. The aneurysm extending over the apex and approx. $1 / 2$ of the anterior wall angina during the period preceding the patient's hospitalization, he was not qualified for coronary revascularization. Surgical reconstruction of the left ventricle was performed by means of the Menicanti method, with the use of an Edwards Bovine Pericardial Patch (produced by Edwards Lifesciences).

After three months of rehabilitation, the patient was reffered for a follow-up appointment. He was in significantly better condition (NYHA functional class II) and during the echocardiography the left ventricular ejection fraction was evaluated at 35\%. By the time of completing this article, about 12 months of follow-up have passed.

\section{Discussion}

The mechanical complications of myocardial infarction include papillary muscle rupture followed by acute mitral valve insufficiency, interventricular septal rupture and free ventricular wall rupture. The ventricular wall rupture results as an ansurysm. The incidence of this complication is estimated for $4 \%$ of patients with myocardial infarction; and $23 \%$ of patients suffering from this condition die [1]. It occurs most frequently in patients with complete left anterior descending artery occlusion and a large area of necrosis. Intravitally, it occurs more frequently in the area vascularized by the right and circumflex arteries, due to the high mortality associated with left anterior descending wall aneurysms [2]. A number of factors predispose to this complication, including elderly age, female sex, arterial hypertension, anterior wall infarction, fibrinolytic treatment, lack of previous coronary episodes, as well as the administration of steroids and non-steroidal anti-inflammatory medications during the acute phase of the infarction. The aneurysm usually develops between the $1^{\text {st }}$ and the $21^{\text {st }}$ day, most frequently on the $5^{\text {th }}$ to $7^{\text {th }}$ day of the infarction [3].

Heart aneurysms can be classified as true or false (pseudoaneurysms); the two types require different treatments and differ in terms of prognosis. A false aneurysm develops as a result of a complete wall rupture within a narrow segment. Its base is usually narrow, and its walls consist only of pericardium and thrombus. The risk of aneurysm rupture

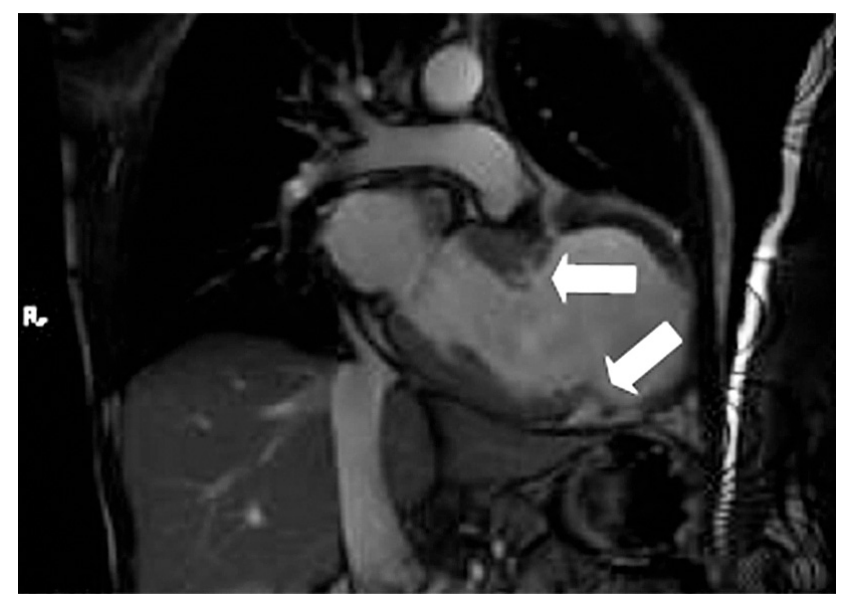

Fig. 3. Magnetic resonance imaging. Sagittal view. The arrows indicate the location of the rupture of the left ventricular muscle 


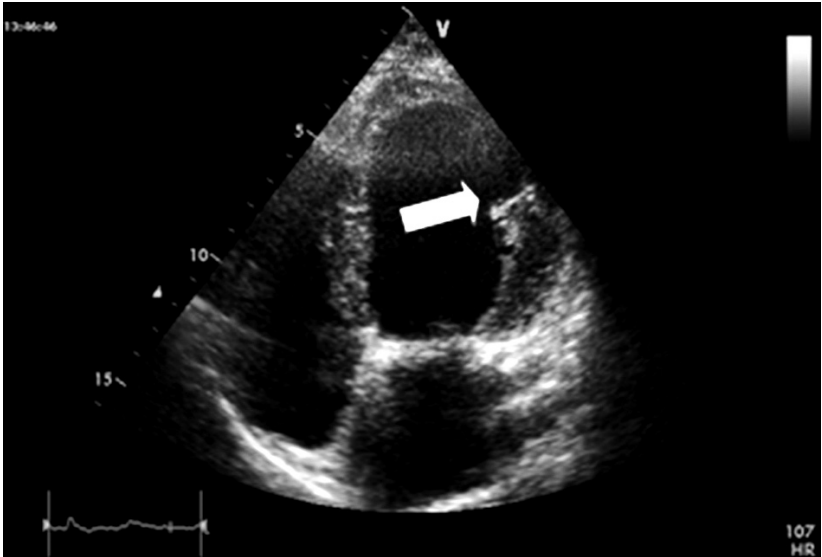

Fig. 4. Echocardiographic examination. Apical four-chamber view. The condition after surgical reconstruction of the left ventricle: the figure presents the location where a patch was sutured into the central segment of the lateral wall

and death is high. The walls of a true aneurysm are constituted by the thinned necrotic myocardium, which is abnormally mobile in relation to the remaining part of the left ventricular muscle. Both aneurysm forms typically impair the heart's pumping function. The primary diagnostic tool enabling the recognition of this complication is echocardiography. In most cases, it allows for the differentiation between true and false aneurysms. In the case of the latter, a Doppler examination may detect blood flow from the ventricular cavity to the aneurysm cavity; in the case of a true aneurysm, one may observe a necrotic area in the form of an akinetic or dyskinetic scar, which is often filled with thrombus due to the slowing down of blood flow in the vicinity of the lesion. If visualization is difficult to achieve, or in case of trouble with determining whether the aneurysm is a true or false, magnetic resonance imaging may be employed. It is not, however, a routine examination procedure in the diagnostics of this complication. In some cases, the aneurysm location may impede echocardiographic imaging and lead to changing the extent of the cardiac surgery.

The differential diagnosis for both aneurysm types has a great impact for further management strategy. While a true aneurysm is a condition in which either surgical or conservative treatment should be considered, a pseudoaneurysm should be treated surgically due to the high risk of rupture, pericardial tamponade, and death. Both aneurysm types may result in congestive heart failure, have high embolic potential, and constitute a substrate for the occurrence of ventricular arrhythmias. The prognosis for patients who have developed severe cardiac insufficiency (NYHA functional class III and/or IV) is particularly unfavorable: only $25 \%$ of them survive more than 3 years [4]. The surgical treatment of post-myocardial infarction heart failure poses certain problems as well. First of all, heart failure, as a nosological entity, constitutes high risk for general anesthesia and extensive procedures using extracorporeal circulation. The Dor procedure, modified by Menicanti, consists

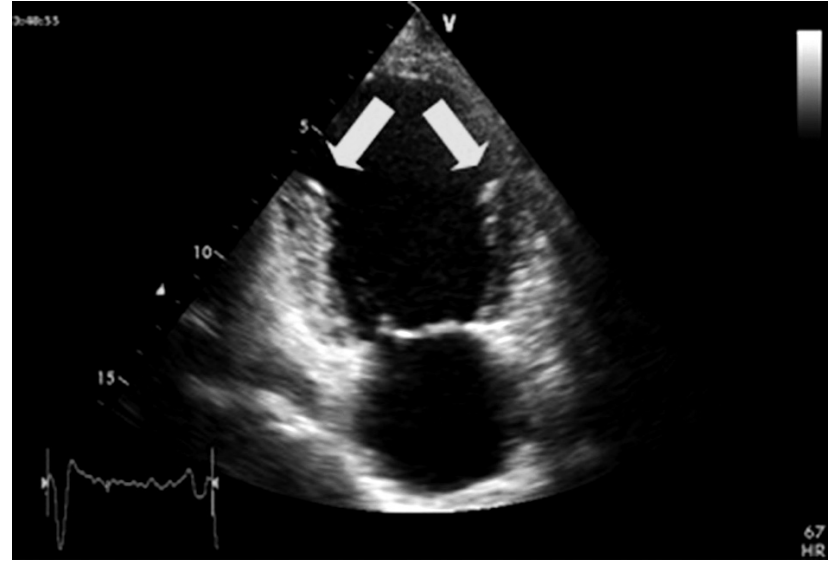

Fig. 5. Apical two-chamber view. The condition after the surgical reconstruction of the left ventricle: the figure presents the location where a patch was sutured into the central segment of the anterior and the inferior wall

in reconstructing and reducing the size of the left ventricle by excising the aneurysm tissue and closing the ventricular cavity with a patch. During the surgery, a special balloon is introduced into the left ventricular cavity; its size is selected individually for each patient, which allows for the close emulation of the physiological size and shape of the left ventricle [5]. Perioperative mortality of approximately $5 \%$ has been reported for this surgical procedure; nevertheless, for most patients with end-stage ischemic heart failure with dilated remodeled left ventricles, the method constitutes one of the few therapeutic options (along with left ventricular assist device implantation and heart transplantation). The diagnosis of pseudoaneurysm should ultimately lead to surgical treatment. However, this is not always the case, mostly because of the patients themselves, as they do not give consent to the strenuous and risky cardiac procedure; as a result we may observe quite a few literature reports describing cases of these patients surviving for many years. Nevertheless, one should consider that the cause of death of patients with chronic pseudoaneurysms may remain undiagnosed. Kocaturk et al. present a case of 4-year survival of a 73-year-old patient with a pseudoaneurysm, pointing out that the risk of perioperative death among patients undergoing surgical repair of the left ventricle amounts to $13-36 \%$, particularly among patients burdened with other chronic diseases, while pharmacological treatment may efficaciously stabilize the patient's condition [6]. In turn, Jiang et al. present a case of 6-year survival of a 75-year-old patient with a pseudoaneurysm, who continued to function without regular complaints and died due to bladder cancer [7]. Moreno et al. describe the results of a 4-year observation of 10 patients (mean age: 63 years) treated conservatively for pseudoaneurysms: none of the patients died due to aneurysm rupture, but 3 of them underwent ischemic strokes during the follow-up period [8]. One of the largest studies devoted to pseudoaneurysms is the analysis of 52 patients, $48 \%$ of whom had their aneurysms diagnosed incidentally. The majority of them (81\%) underwent a surgi- 
cal procedure; 19 died within 2.3 years of follow-up (including 13 patients who underwent surgery), but a repeated rupture of the heart wall was not observed in any of them [9]. Treating pseudoaneurysms should, in most cases, lead to surgical treatment, particularly in the case of younger patients who are not burdened with other diseases.

The presented case study demonstrates that, despite high perioperative risk, the chances of surgical success and improving the patient's condition are substantial. Nonetheless, in the case of elderly patients, the arguments for and against surgery should be considered carefully - the presented literature indicates that the risk associated with aneurysm rupture may be lower than the risk associated with surgical treatment.

\section{References}

1. Pollak H, Nobis H, Mlczoch J. Frequency of left ventricular free wall rupture complicating acute myocardial infarction since the advent of thrombolysis. Am J Cardiol 1994; 74: 2184-2186.
2. Zoffoli G, Mangino D, Venturini A, Terrini A, Asta A, Zanchettin Ch, Polesel E. Diagnosing left ventricular aneurysm from pseudo-aneurysm: a case report and a review in literature. J Cardiovasc Surg 2009; 4: 11.

3. Raposo L, Andrade M, Ferreira J, Aguiar C, Couto R, Abecasis M, Canada M, Jalles-Tavares N, A da Silva J. Subacute left ventricle free wall rupture after acute myocardial infarction: awareness of the clinical signs and early use of echocardiography may be life-saving. Cardiovasc Ultrasound 2006, 4: 46

4. Levy D, Kenchaiah S, Larson MG, Benjamin EJ, Kupka MJ, Ho KK, Murabito JM, Vasan RS. Long-term trends in the incidence of and survival with heart failure. Framingham Heart Study. N Engl J Med 2002; 347: 1397-1402.

5. Menicanti L, Castelvecchio S, Ranucci M, Frigiola A, Santambrogio C, de Viincentiis C, Brankovic J, Di Donato M. Surgical therapy for ischemic heart failure: single-center experience with surgical anterior ventricular restoration. J Thorac Cardiovasc Surg 2007; 134: 433-441.

6. Kocaturk H, Karaman A, Bayram E, Çolak M. Left ventricular pseudoaneurysm: A four year follow-up with medical therapy. N J Med 2011; 28: 59-61.

7. Jiang Ch, Zhao R, Yang X. Six-year follow-up of a left ventricular pseudoaneurysm without surgical repair. Can J Cardiol 2007; 23: 739-741.

8. Moreno R, Gordillo E, Zamorano J, Almeria C, Garcia-Rubira JC, FernandezOritz A, Macaya C. Long term outcome of patients with postinfarction left ventricular pseudoaneurysm. Heart 2003; 89: 1144-1146.

9. Yeo TC, Malouf JF, Oh JK, Seward JB. Clinical profile and outcome in 52 patients with cardiac pseudoaneurysm. Ann Intern Med 1998; 128: 299-305. 